\title{
The effect of collecting area on the element content of Hungarian acacia honeys
}

\author{
NIKOLETT CZIPA - ANDREA KÁNTOR - LORÁND ALEXA - BÉLA KOVÁCS \\ University of Debrecen, Institute of Food Science, Debrecen, Hungary \\ czipa@agr.unideb.hu
}

\section{Summary}

Six macroelements and twelve microelements were identified in thirty-six Hungarian acacia honeys collected from ten counties by inductively coupled plasma optical emission spectrometry (ICP-OES) and inductively coupled plasma mass spectrometry (ICP-MS). One-Way ANOVA (LSD and Dunnett T3 test) and linear discriminant analysis (LDA) were used to determine the statistically verified differences among the honey samples with different geographical origin.

Significant differences were established among the samples from different counties in $\mathrm{Na}, \mathrm{P}, \mathrm{S}, \mathrm{Fe}, \mathrm{Ni}, \mathrm{Cu}$ and $\mathrm{Sr}$ concentrations. Based on the macroelement content of honeys, the separation of samples with different geographical origin was not successful because the percent of correctly categorised cases was only $64.9 \%$. However, examining the $\mathrm{As}, \mathrm{B}, \mathrm{Ba}, \mathrm{Cu}, \mathrm{Fe} \mathrm{Mn}, \mathrm{Ni}$ and $\mathrm{Sr}$ concentration, the separation of different groups was convincing since the percent of correctly classified cases was $97.2 \%$. Thus, the examination of microelement concentration may be able to determine the geographical origin of acacia honeys.

Keywords: acacia honey, collecting area, element content

\section{Introduction}

Honey is a natural substance produced by Apis mellifera bees from nectar and/or honeydew. In Hungary the annual honey production was 26,360 tonnes in 2016 (FAOSTAT) due to the environmental conditions of our countries that are favourable for honey production. Honey is a very complex food containing many essential nutrients, in particular micro and trace elements, proteins, amino acids, vitamins and enzymes. The botanical origin, harvesting treatment and storage has important effect to the composition and properties of honeys. Honey has a low mineral content $(0.1-0.2 \%$ in nectar honeys) which varies depending on the soil conditions (Pohl et al., 2012) and extraction techniques (Hernández et al., 2005), rendering it suitable as an environmental indicator (Almeida-Silva et al., 2011). Anthropogenic activities (e.g. smelting, burning of fossil fuel, use of fertilizers and pesticides, transport) may also affect soil and air properties that influence the trace element content of plants (KabataPendias and Mukherjee, 2007). 
The aims of this study were to: (i) determine the macro, micro and trace element content in 36 Hungarian acacia honeys; (ii) test the influence of the collecting area on the element content of examined acacia honey samples.

\section{Materials and methods}

\section{Honey samples}

In this study 36 acacia (Robinia pseudoacacia) honey samples were analysed. All samples were collected from Hungarian beekeepers from 10 counties of Hungary (Table 1). The collecting year of examined samples was 2016; all samples were collected and stored in new, sterile glass jars at room temperature in the dark until analysis. Melissopalynological analysis was carried out to determine the botanical origin of examined honey samples using the method described by MSZ 6950-3:1977 (microscopic analysis of honey). Predominant pollen ( $>50 \%$ of pollen grains counted) was determined.

Table 1. Geographical origin of examined samples

\begin{tabular}{|c|c|c|}
\hline Sample & County & Abbrevation \\
\hline $1-5$ & Hajdú-Bihar & $\mathrm{HB}$ \\
\hline $6-8$ & Békés & $\mathrm{BE}$ \\
\hline $9-14$ & Szabolcs-Szatmár-Bereg & SSB \\
\hline $15-17$ & Bács-Kiskun & BK \\
\hline $18-20$ & Csongrád & CS \\
\hline $21-24$ & Borsod-Abaúj-Zemplén & BAZ \\
\hline $25-27$ & Heves & $\mathrm{HE}$ \\
\hline $28-30$ & Zala & $\mathrm{ZA}$ \\
\hline $31-33$ & Baranya & BA \\
\hline $34-36$ & Veszprém & VE \\
\hline
\end{tabular}

\section{Determination of element content}

The digestions of honey samples were carried out according to the method of Kovács et al. (1996). Nitric acid $(69 \% \mathrm{v} / \mathrm{v})$ and hydrogenperoxide $(30 \% \mathrm{v} / \mathrm{v})$ from VWR International Ltd. (Radnor, USA) were used to the digestion of samples and ultrapure water produced by a Milli-Q water purification system (Millipore SAS, Molsheim, France) was used to the preparation of solutions and dilutions. Depending on the anticipated concentration, determination of $\mathrm{B}, \mathrm{Ca}, \mathrm{K}, \mathrm{Mg}, \mathrm{Na}, \mathrm{P}$ and $\mathrm{S}$ was carried out using ICP-OES (Inductively Coupled Plasma Optical Emission Spectrometry; Thermo Scientific iCAP 6300, Cambridge, UK) and determination of $\mathrm{Al}, \mathrm{Mn}, \mathrm{Fe}, \mathrm{Ni}, \mathrm{Cu}, \mathrm{Zn}, \mathrm{As}, \mathrm{Sr}, \mathrm{Cd}, \mathrm{Ba}$ and $\mathrm{Pb}$ was carried out using ICP-MS (Inductively Couples Plasma Mass Spectrometry; Thermo Scientific XSeries 2, Bremen, Germany). The 
applied wavelengths, isotopes and LDs (detection of limits) are shown in Table 2.

Table 2. Applied wavelengths and isotopes and LDs

\begin{tabular}{|c|c|c|}
\hline \multicolumn{3}{|c|}{ ICP-OES } \\
\hline Elements & Wavelengths (nm) & LDs (mg kg-1) \\
\hline B & 249.6 & 0.12 \\
\hline $\mathrm{Ca}$ & 317.9 & 2.38 \\
\hline K & 766.4 & 0.53 \\
\hline $\mathrm{Mg}$ & 279.5 & 0.10 \\
\hline $\mathrm{Na}$ & 589.5 & 0.49 \\
\hline $\mathrm{P}$ & 185.9 & 0.49 \\
\hline S & 182.0 & 0.11 \\
\hline \multicolumn{3}{|c|}{ ICP-MS } \\
\hline Elements & Isotopes (amu) & LODs $\left(\mu \mathrm{g} \mathrm{kg}^{-1}\right)$ \\
\hline $\mathrm{Al}$ & 27 & 39.90 \\
\hline Mn & 55 & 3.44 \\
\hline $\mathrm{Fe}$ & 56 & 77.40 \\
\hline $\mathrm{Ni}$ & 60 & 2.92 \\
\hline $\mathrm{Cu}$ & 65 & 27.40 \\
\hline $\mathrm{Zn}$ & 66 & 45.30 \\
\hline As & 75 & 1.19 \\
\hline $\mathrm{Sr}$ & 88 & 1.09 \\
\hline $\mathrm{Cd}$ & 111 & 0.19 \\
\hline $\mathrm{Ba}$ & 137 & 0.65 \\
\hline $\mathrm{Pb}$ & 206 & 0.93 \\
\hline
\end{tabular}

\section{Statistical analysis}

All analytical analysis was carried out in triplicate. Data are described using general terms (mean, standard deviation, minimum and maximum values), One-Way ANOVA with LSD or Dunnett T3 tests and LDA (Linear Discriminant Analysis). SPSS for Windows (version 13; SPSS Inc. Chicago, Illinois, USA) was used for all calculations.

\section{Results and discussion}

The element concentration of examined Hungarian acacia honey samples are shown in Table 3. According to total element concentrations K $(164 \pm 43$ $\mathrm{mg} \mathrm{kg}^{-1}$ ) was the most abundant of the minerals analysed followed by $\mathrm{P}$ $\left(41.8 \pm 6.6 \mathrm{mg} \mathrm{kg}^{-1}\right), \mathrm{S}\left(15.6 \pm 3.1 \mathrm{mg} \mathrm{kg}^{-1}\right), \mathrm{Ca}\left(13.1 \pm 3.6 \mathrm{mg} \mathrm{kg}^{-1}\right), \mathrm{Mg}$ $\left(4.91 \pm 0.81 \mathrm{mg} \mathrm{kg}^{-1}\right)$ and $\mathrm{Na}\left(3.54 \pm 0.75 \mathrm{mg} \mathrm{kg}^{-1}\right)$. The highest $\mathrm{K}$ content was measured in a sample from HB $\left(287 \pm 4 \mathrm{mg} \mathrm{kg}^{-1}\right)$ and the lowest concentration was determined in a sample from BK $\left(111 \pm 4 \mathrm{mg} \mathrm{kg}^{-1}\right)$.

Samples from HB showed the highest mean K concentration $(229 \pm 47$ $\mathrm{mg} \mathrm{kg} \mathrm{k}^{-1}$ and the lowest mean $\mathrm{K}$ content were measured in samples from 
$\mathrm{BE}\left(125 \pm 6 \mathrm{mg} \mathrm{kg}^{-1}\right)$ and BK $\left(130 \pm 27 \mathrm{mg} \mathrm{kg}^{-1}\right)$. The $\mathrm{P}$ concentrations were ranged between $32.0 \pm 1.2 \mathrm{mg} \mathrm{kg}^{-1}(\mathrm{BK})$ and $56.1 \pm 0.6 \mathrm{mg} \mathrm{kg}^{-1}$ (VE). Examining the counties, samples from VE showed the highest $(52.4 \pm 3.6$ $\mathrm{mg} \mathrm{kg}^{-1}$ ) and $\mathrm{BE}$ and $\mathrm{BAZ}$ showed the lowest mean $\mathrm{P}$ concentrations $\left(33.6 \pm 1.5\right.$ and $\left.33.9 \pm 1.4 \mathrm{mg} \mathrm{kg}^{-1}\right)$. The highest and lowest $\mathrm{S}$ contents were measured in a sample from HB $\left(22.9 \pm 0.3 \mathrm{mg} \mathrm{kg}^{-1}\right)$ and BE $(7.21 \pm 0.03 \mathrm{mg}$ $\left.\mathrm{kg}^{-1}\right)$. The mean $\mathrm{S}$ concentrations of samples from different counties showed similar results.

The samples from HB showed the highest $S$ content $\left(20.1 \pm 2.3 \mathrm{mg} \mathrm{kg}^{-1}\right)$ and the samples from BE showed the lowest $S$ concentrations $(10.0 \pm 0.4$ $\mathrm{mg} \mathrm{kg}-1$ ).The lowest $\mathrm{Ca}$ content was determined in a sample from BE $\left(7.21 \pm 0.6 \mathrm{mg} \mathrm{kg}^{-1}\right)$ and the samples from this county showed the lowest mean $\mathrm{Ca}$ concentrations $\left(7.94 \pm 0.65 \mathrm{mg} \mathrm{kg}^{-1}\right)$. Similar mean Ca concentrations were measured in samples from CS and BA $(8.54 \pm 0.21$ and $\left.8.55 \pm 0.53 \mathrm{mg} \mathrm{kg}^{-1}\right)$. Samples from SSB showed the highest mean Ca contents $\left(17.2 \pm 1.6 \mathrm{mg} \mathrm{kg}^{-1}\right)$; however the highest $\mathrm{Ca}$ concentration was measured in a sample from VE $\left(19.5 \pm 0.3 \mathrm{mg} \mathrm{kg}^{-1}\right)$.

Analysed samples showed similar mean $\mathrm{Mg}, \mathrm{Na}$ and $\mathrm{B}$ contents. $\mathrm{Mg}$ concentrations ranged from $3.64 \pm 0.05 \mathrm{mg} \mathrm{kg}^{-1}$ (CS) to $6.92 \pm 0.06 \mathrm{mg} \mathrm{kg}^{-1}$ (VE); however the mean $\mathrm{Mg}$ content of samples from different counties did not show big variance. The lowest mean values were determined in samples from CS and ZA (4.14 \pm 0.59 and $\left.4.20 \pm 0.10 \mathrm{mg} \mathrm{kg}^{-1}\right)$ and the highest mean contents were measured in samples from $\mathrm{HB}, \mathrm{HE}$ and VE $\left(5.78 \pm 0.57,5.77 \pm 0.67\right.$ and $\left.5.64 \pm 1.11 \mathrm{mg} \mathrm{kg}^{-1}\right)$. The highest $\mathrm{Na}$ content was measured in a sample from BA $\left(1.89 \pm 0.06 \mathrm{mg} \mathrm{kg}^{-1}\right)$ and the mean $\mathrm{Na}$ concentration of samples from different counties was the lowest in samples from VE and BA $\left(2.42 \pm 0.61\right.$ and $\left.2.50 \pm 0.54 \mathrm{mg} \mathrm{kg}^{-1}\right)$. The highest $\mathrm{Na}$ concentration was determined in a sample from HB $(5.20 \pm 0.11 \mathrm{mg} \mathrm{kg}$ 1) and the samples from this country showed the highest mean $\mathrm{Na}$ content $\left(4.53 \pm 0.55 \mathrm{mg} \mathrm{kg}^{-1}\right)$.

Samples from HE showed the highest mean B content $(3.85 \pm 0.37 \mathrm{mg}$ $\mathrm{kg}^{-1}$ ) and a sample from this county showed the highest $\mathrm{B}$ concentration $\left(4.28 \pm 0.12 \mathrm{mg} \mathrm{kg}^{-1}\right)$. The lowest B content was measured in a sample from ZA $\left(2.03 \pm 0.02 \mathrm{mg} \mathrm{kg}^{-1}\right)$ and samples from this county showed the lowest mean B concentration $\left(2.57 \pm 0.27 \mathrm{mg} \mathrm{kg}^{-1}\right)$.

Examining the element content of samples from 10 counties statistically verified differences $(\mathrm{p}<0.05)$ were determined in 14 cases for K, 22 cases for $\mathrm{Na}, 13$ cases for $\mathrm{Ca}, 28$ cases for $\mathrm{P}, 22$ cases for $\mathrm{S}, 15$ cases for $\mathrm{Mg}$ and 11 cases for $\mathrm{B}$. Therefore the highest differences in element content of samples from different counties were found in case of $\mathrm{P}, \mathrm{S}$ and Na content. 
Table 3. Macro- and microelement contents of examined acacia samples with different geographical origin

\begin{tabular}{|c|c|c|c|c|c|}
\hline & $\begin{array}{c}\text { HB } \\
(n=5)\end{array}$ & $\begin{array}{c}\text { BÉ } \\
(n=3)\end{array}$ & $\begin{array}{c}\text { SSB } \\
(\mathrm{n}=6)\end{array}$ & $\begin{array}{c}\text { BK } \\
(n=3)\end{array}$ & $\begin{array}{c}C S \\
(n=3)\end{array}$ \\
\hline $\mathrm{Ca}$ & $15.8 \pm 2.2$ & $7.94 \pm 0.64$ & $17.2 \pm 1.6$ & $15.1 \pm 0.9$ & $8.54 \pm 0.21$ \\
\hline K & $229 \pm 45$ & $125 \pm 6$ & $154 \pm 30$ & $130 \pm 27$ & $143 \pm 34$ \\
\hline $\mathrm{Mg}$ & $5.78 \pm 0.59$ & $4.28 \pm 0.29$ & $4.81 \pm 0.71$ & $4.74 \pm 0.34$ & $4.14 \pm 0.59$ \\
\hline $\mathrm{Na}$ & $4.53 \pm 5.54$ & $3.11 \pm 0.23$ & $3.76 \pm 0.49$ & $3.39 \pm 0.12$ & $3.74 \pm 0.29$ \\
\hline $\mathrm{P}$ & $44.4 \pm 5.1$ & $33.6 \pm 1.5$ & $46.3 \pm 4.7$ & $36.6 \pm 4.0$ & $36.6 \pm 1.3$ \\
\hline$S$ & $20.1 \pm 2.3$ & $10.0 \pm 0.4$ & $15.5 \pm 1.5$ & $12.8 \pm 0.8$ & $15.6 \pm 2.3$ \\
\hline $\mathrm{Al}$ & $133 \pm 46$ & $293 \pm 19$ & $129 \pm 44$ & $<\mathrm{LD}$ & $149 \pm 22$ \\
\hline As & $12.3 \pm 2.4$ & $6.92 \pm 0.24$ & $41.1 \pm 2.1$ & $29.7 \pm 2.1$ & $35.0 \pm 3.5$ \\
\hline B & $2.84 \pm 0.67$ & $2.95 \pm 0.7$ & $3.53 \pm 0.32$ & $3.19 \pm 0.61$ & $3.42 \pm 0.29$ \\
\hline $\mathrm{Ba}$ & $15.3 \pm 5.3$ & $79.6 \pm 3.1$ & $20.5 \pm 5.8$ & $8.14 \pm 0.26$ & $5.54 \pm 1.02$ \\
\hline $\mathrm{Cd}$ & $0.45 \pm 0.12$ & $<\mathrm{LD}$ & $<\mathrm{LD}$ & $<\mathrm{LD}$ & $<\mathrm{LD}$ \\
\hline $\mathrm{Cu}$ & $141 \pm 24$ & $69.8 \pm 2.0$ & $118 \pm 14$ & $155 \pm 11$ & $170 \pm 4$ \\
\hline $\mathrm{Fe}$ & $597 \pm 51$ & $315 \pm 9$ & $583 \pm 66$ & $310 \pm 14$ & $1175 \pm 44$ \\
\hline $\mathrm{Mn}$ & $186 \pm 62$ & $68.5 \pm 2.8$ & $114 \pm 9$ & $63.5 \pm 11.5$ & $50.6 \pm 1.0$ \\
\hline $\mathrm{Ni}$ & $25.0 \pm 3.4$ & $29.8 \pm 1.0$ & $24.9 \pm 3.3$ & $14.0 \pm 1.8$ & $12.3 \pm 1.5$ \\
\hline $\mathrm{Pb}$ & $<\mathrm{LD}$ & $<\mathrm{LD}$ & $6.35^{*}$ & $<\mathrm{LD}$ & $8.65 \pm 0.82$ \\
\hline Sr & $26.1 \pm 3.1$ & $16.4 \pm 0.5$ & $22.3 \pm 3.3$ & $18.2 \pm 2.6$ & $22.3 \pm 2.4$ \\
\hline \multirow[t]{2}{*}{$\mathrm{Zn}$} & $238 \pm 33$ & $151 \pm 10$ & $104 \pm 12$ & $351 \pm 26$ & $248 \pm 3$ \\
\hline & $\begin{array}{l}\text { BAZ } \\
(n=4)\end{array}$ & $\begin{array}{c}\mathrm{HE} \\
(\mathrm{n}=3)\end{array}$ & $\begin{array}{c}\mathrm{ZA} \\
(\mathrm{n}=3)\end{array}$ & $\begin{array}{c}\text { BA } \\
(\mathrm{n}=3)\end{array}$ & $\begin{array}{c}\mathrm{VE} \\
(\mathrm{n}=3)\end{array}$ \\
\hline $\mathrm{Ca}$ & $11.4 \pm 0.8$ & $12.7 \pm 1.1$ & $11.8 \pm 1.6$ & $8.55 \pm 0.53$ & $16.0 \pm 3.0$ \\
\hline $\mathrm{K}$ & $163 \pm 32$ & $146 \pm 30$ & $201 \pm 25$ & $144 \pm 31$ & $169 \pm 33$ \\
\hline $\mathrm{Mg}$ & $4.67 \pm 0.80$ & $5.77 \pm 0.67$ & $4.20 \pm 0.10$ & $4.71 \pm 0.39$ & $5.64 \pm 1.11$ \\
\hline $\mathrm{Na}$ & $4.19 \pm 0.51$ & $3.51 \pm 0.27$ & $3.18 \pm 0.07$ & $2.50 \pm 0.54$ & $2.42 \pm 0.61$ \\
\hline $\mathrm{P}$ & $33.9 \pm 1.4$ & $43.3 \pm 1.3$ & $47.0 \pm 1.3$ & $40.2 \pm 4.2$ & $52.4 \pm 3.6$ \\
\hline S & $18.1 \pm 0.7$ & $15.8 \pm 2.4$ & $15.7 \pm 0.9$ & $14.5 \pm 2.1$ & $14.3 \pm 2.0$ \\
\hline $\mathrm{Al}$ & $151 \pm 36$ & $104 \pm 9$ & $113 \pm 7$ & $99.3 \pm 11.6$ & $149 \pm 32$ \\
\hline As & $7.43 \pm 1.4$ & $29.1 \pm 2.4$ & $18.3 \pm 1.5$ & $34.5 \pm 1.3$ & $14.6 \pm 1.0$ \\
\hline B & $3.05 \pm 0.17$ & $3.85 \pm 0.40$ & $2.57 \pm 0.27$ & $2.62 \pm 0.25$ & $3.09 \pm 0.30$ \\
\hline $\mathrm{Ba}$ & $12.7 \pm 1.8$ & $14.4 \pm 0.7$ & $21.0 \pm 1.6$ & $10.0 \pm 2.4$ & $19.9 \pm 2.2$ \\
\hline $\mathrm{Cd}$ & $0.09 \pm 0.04$ & $0.33 \pm 0.04$ & $<\mathrm{LD}$ & $<\mathrm{LD}$ & $<\mathrm{LD}$ \\
\hline $\mathrm{Cu}$ & $135 \pm 11$ & $155 \pm 29$ & $232 \pm 25$ & $172 \pm 7$ & $76.4 \pm 3.4$ \\
\hline $\mathrm{Fe}$ & $567 \pm 54$ & $442 \pm 23$ & $723 \pm 11$ & $137 \pm 5$ & $614 \pm 24$ \\
\hline Mn & $88.7 \pm 6.1$ & $90.3 \pm 2.6$ & $43.6 \pm 3.4$ & $59.0 \pm 4.7$ & $51.6 \pm 1.7$ \\
\hline $\mathrm{Ni}$ & $17.4 \pm 2.2$ & $105 \pm 5$ & $24.8 \pm 1.6$ & $21.5 \pm 2.3$ & $19.8 \pm 1.1$ \\
\hline $\mathrm{Pb}$ & $31.1^{*}$ & $<\mathrm{LD}$ & $8.64 \pm 0.80$ & $4.20 \pm 0.24$ & $<\mathrm{LD}$ \\
\hline $\mathrm{Sr}$ & $16.4 \pm 3.2$ & $22.9 \pm 2.4$ & $10.5 \pm 0.3$ & $13.0 \pm 1.9$ & $17.3 \pm 1.6$ \\
\hline $\mathrm{Zn}$ & $1583 \pm 299$ & $240 \pm 21$ & $185 \pm 10$ & $<\mathrm{LD}$ & $131 \pm 23$ \\
\hline
\end{tabular}

Note: $\mathrm{Ca}, \mathrm{K}, \mathrm{Mg}$, Na, P, S and B expressed in $\mathrm{mg} \mathrm{kg}^{-1}$; Al, As, Ba, Cd, Cu, Fe, Mn, Ni, Pb, Sr and $\mathrm{Zn}$ expressed in $\mu \mathrm{g} \mathrm{kg}{ }^{-1},{ }^{*} \mathrm{~Pb}$ content were measured only one sample.

Al concentrations were under LD in samples from BK and the samples from BA also showed lower $\mathrm{Zn}$ content than the LD. Pb concentrations could be measured only in 11 samples (1 sample from SSB, every sample from CS, ZA and BA and 1 sample from BAZ. Cd content was above LD in 12 samples (every sample from $\mathrm{HB}, \mathrm{BAZ}$ and $\mathrm{HE}$ counties). 
Examining the micro element concentrations of samples, considered separately, the lowest $\mathrm{Al}, \mathrm{Ba}, \mathrm{Cu}, \mathrm{Fe}, \mathrm{Mn}, \mathrm{Ni}, \mathrm{Sr}$ and $\mathrm{Zn}$ contents were measured in the following sample from BA $(87.0 \pm 2.3 \mu \mathrm{g} \mathrm{kg}-1)$, CS $\left(4.36 \pm 0.12 \mu \mathrm{g} \mathrm{kg}^{-1}\right), \mathrm{BE}\left(67.5 \pm 1.1 \mu \mathrm{g} \mathrm{kg}^{-1}\right), \mathrm{BA}\left(134 \pm 2 \mu \mathrm{g} \mathrm{kg}{ }^{-1}\right), \mathrm{ZA}(39.9 \pm 0.5$ $\left.\mu \mathrm{g} \mathrm{kg}^{-1}\right), \mathrm{CS}\left(10.9 \pm 0.2 \mu \mathrm{g} \mathrm{kg}^{-1}\right), \mathrm{ZA}\left(10.2 \pm 0.3 \mu \mathrm{g} \mathrm{kg}^{-1}\right)$ and SSB $(91.0 \pm 1.5 \mu \mathrm{g}$ $\mathrm{kg}^{-1}$ ) county. The highest $\mathrm{Al}, \mathrm{Ba}, \mathrm{Cu}, \mathrm{Fe}, \mathrm{Mn}, \mathrm{Ni}, \mathrm{Sr}$ and $\mathrm{Zn}$ concentrations were measured in the following sample from BE $\left(310 \pm 6 \mu \mathrm{g} \mathrm{kg}^{-1}\right), \mathrm{BE}$ $\left(82.1 \pm 1.0 \mu \mathrm{g} \mathrm{kg}^{-1}\right), \mathrm{ZA}\left(256 \pm 3 \mu \mathrm{g} \mathrm{kg}^{-1}\right), \mathrm{CS}\left(1212 \pm 13 \mu \mathrm{g} \mathrm{kg}^{-1}\right), \mathrm{HB}(230 \pm 6 \mu \mathrm{g}$ $\left.\mathrm{kg}^{-1}\right)$, HE $\left(110 \pm 3 \mu \mathrm{g} \mathrm{kg}^{-1}\right), \mathrm{HB}\left(29.5 \pm 1.1 \mu \mathrm{g} \mathrm{kg}^{-1}\right)$ and BAZ $\left(1940 \pm 12 \mu \mathrm{g} \mathrm{kg}^{-1}\right)$ county.

Examining the micro element concentrations by county, the lowest mean $\mathrm{Al}, \mathrm{Ba}, \mathrm{Cu}, \mathrm{Fe}, \mathrm{Mn}, \mathrm{Ni}, \mathrm{Sr}$ and $\mathrm{Zn}$ contents of different counties was measured in samples from BA $\left(99.3 \pm 11.6 \mu \mathrm{g} \mathrm{kg}^{-1}\right)$, CS $\left(5.54 \pm 1.02 \mu \mathrm{g} \mathrm{kg}^{-1}\right)$, BE $\left(69.8 \pm 2.0 \mu \mathrm{g} \mathrm{kg}^{-1}\right), \mathrm{BA}\left(137 \pm 5 \mu \mathrm{g} \mathrm{kg}{ }^{-1}\right), \mathrm{ZA}(43.6 \pm 3.4 \mu \mathrm{g} \mathrm{kg}-1), \mathrm{CS}$ $\left(12.3 \pm 1.5 \mu \mathrm{g} \mathrm{kg}^{-1}\right), \mathrm{ZA}\left(10.5 \pm 0.3 \mu \mathrm{g} \mathrm{kg}^{-1}\right)$ and SSB $(104 \pm 12 \mu \mathrm{g} \mathrm{kg}-1)$ county.

The highest $\mathrm{Al}, \mathrm{Ba}, \mathrm{Cu}, \mathrm{Fe}, \mathrm{Mn}, \mathrm{Ni}, \mathrm{Sr}$ and $\mathrm{Zn}$ concentrations of different counties was determined in samples from BE $\left(292 \pm 19 \mu \mathrm{g} \mathrm{kg}^{-1}\right)$, BE $\left(79.6 \pm 3.1 \mu \mathrm{kg}^{-1}\right)$, ZA $(232 \pm 25 \mu \mathrm{g} \mathrm{kg}-1)$, CS $\left(1175 \pm 44 \mu \mathrm{g} \mathrm{kg}^{-1}\right), \mathrm{HB}$ $\left(186 \pm 62 \mu \mathrm{g} \mathrm{kg}^{-1}\right), \mathrm{HE}\left(105 \pm 5 \mu \mathrm{g} \mathrm{kg}{ }^{-1}\right), \mathrm{HB}\left(26.1 \pm 3.1 \mu \mathrm{g} \mathrm{kg}^{-1}\right)$ and BAZ $\left(1583 \pm 299 \mu \mathrm{g} \mathrm{kg}^{-1}\right)$ county.

Statistically verified differences were found among the micro element contents of the most examined samples from different counties mainly in case of $\mathrm{Fe}$ (32 cases), Ni (34 cases), Cu (32 cases) and $\mathrm{Sr}$ ( 29 cases).

In our study the samples collected in different counties showed statistically verified differences in case of element content. However, in our previous studies we verified the macro element content of honeys depends on mainly the botanical origin (Czipa et al., 2018) and the effect of collecting area on the macro element concentration of different honey types is not so significant (Czipa et al., 2017). Conversely the micro element content of honeys is influenced by collecting area; therefore we suppose that when we would like to determine statistically verified differences among the honeys with same botanical origin; we have to examine the micro element contents. For this reason more LDAs were carried out to confirmation this hypothesis.

Figure 1 showed the results of LDA when only macro elements were analysed. Examining the equality of group means, based on the Wilks' Lambda Ca had the highest effect to the discriminant function (0.189) followed by P (0.214), S (0.227), Na (0.249), K (0.415) and Mg (0.457). Every variable were significant $(\mathrm{P}$ value $<0.005)$. Six canonical discriminant functions were used in the analysis. The correlation was very high in case of first and second function (0.962 and 0.951). Third and fourth function showed middle correlation (0.784 and 0.709) and fifth and sixth function showed the lowest correlation (0.653 and 0.468). The first 
function explained $92.5 \%$, the second $90.4 \%$, the third $61.5 \%$, the fourth $50.3 \%$, the fifth $42.6 \%$ and the sixth $21.9 \%$. In the first dimension honeys from VE showed the highest group centroid (6.29) followed by honeys from SSB (2.63), ZA (1.40), BK (0.87) and HE (0.35). Centroid values was lower than zero in case of honeys from BA $(-0.22), \mathrm{BE}(-0.71), \mathrm{HB}(-1.86)$, CS (-3.39) and BAZ (-5.07). In the second dimension honeys from SSB showed the highest group centroid (3.10) followed by honeys from HB (3.00), BAZ (1.15) and BK (0.39). Centroid value was lower than zero in case of honeys from ZA (-0.59) followed by honeys from HE (-1.08), VE ($1.12), \mathrm{CS}(-1.22), \mathrm{BA}(-4.09)$ and BE (-5.02).

Figure 1. LDA of acacia honeys examining $\mathrm{K}, \mathrm{Ca}, \mathrm{Mg}, \mathrm{Na}, \mathrm{P}$ and $\mathrm{S}$

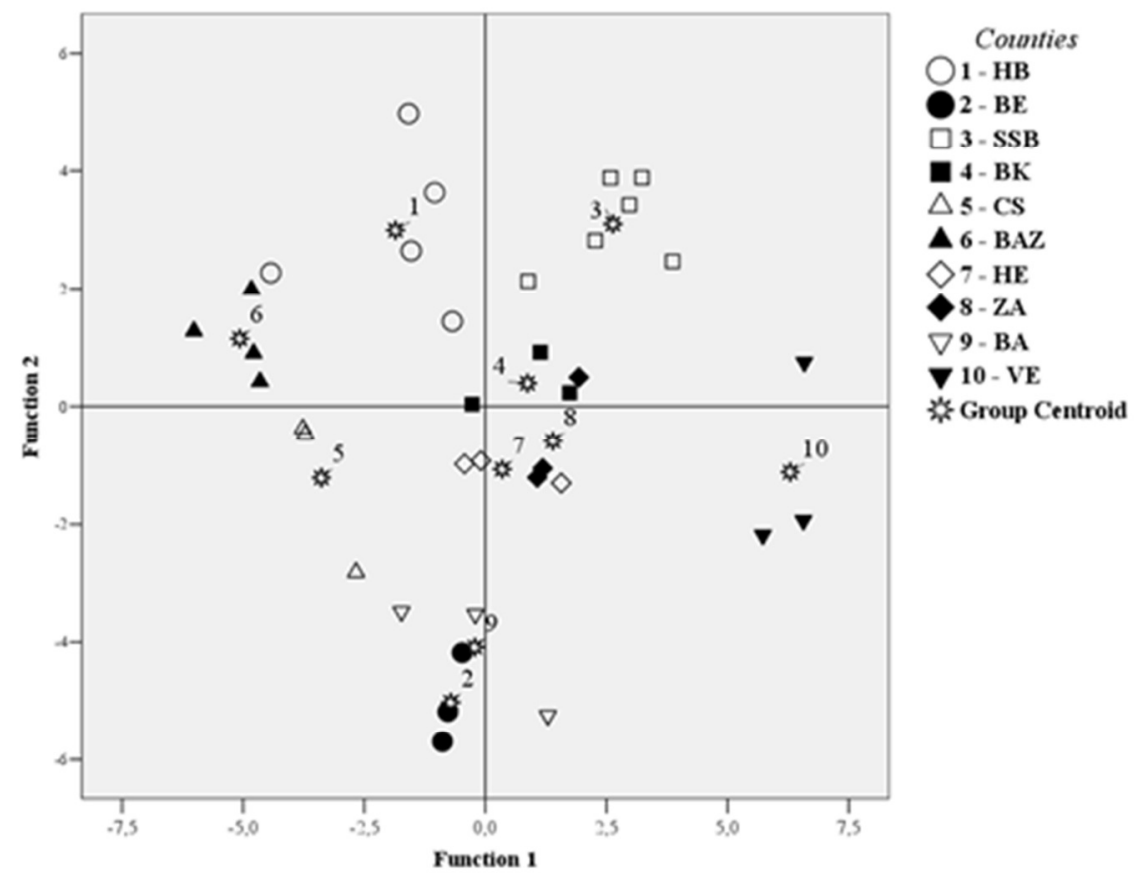

According to the cross validation in case of honeys from $\mathrm{HB}$ the number of correctly categorized cases was only 1 (20\%), with 1-1 sample in the group of SSB, BK, BAZ and HE. In case of honeys from SSB this number was $5(83.3 \%)$, because 1 sample was assigned to the group of BK. In case of honeys from CS this number was only 1 (33.3\%), with 1-1 sample in the group of BE and BAZ. This number was only 1 in case of honeys from HE, because 1 sample was assigned to the group of ZA and BA. In case of honeys from BA this number was also only 1, with 1-1 sample in the group of BE and HE. The percent of correctly categorized 
cases was $100 \%$ in case of honeys from BE, BK, BAZ, ZA and VE. Overall $69.4 \%$ of cross-validated grouped cases were correctly classified.

From the examined micro elements, $\mathrm{As}, \mathrm{B}, \mathrm{Ba}, \mathrm{Cu}, \mathrm{Fe}, \mathrm{Mn}, \mathrm{Ni}$ and $\mathrm{Sr}$ concentration were involved in $\mathrm{LDA} . \mathrm{Al}, \mathrm{Zn}, \mathrm{Cd}$ and $\mathrm{Pb}$ content were missed out from this analysis because these elements were not measured in every sample. The result of LDA showed in Figure 2. According to the Wilks'Lambda (based on the test of equality of group means) every variables has significant effect and $\mathrm{Ni}(0.009)$ has the highest effect to the discriminant function followed by As (0.018), Fe (0.021), Ba (0.026), Cu (0.099), Sr (0.184), Mn (0.186) and B (0.445).

Figure 2. LDA of acacia honeys examining $\mathrm{As}, \mathrm{B}, \mathrm{Ba}, \mathrm{Cu}, \mathrm{Fe}, \mathrm{Mn}, \mathrm{Ni}$ and $\mathrm{Sr}$

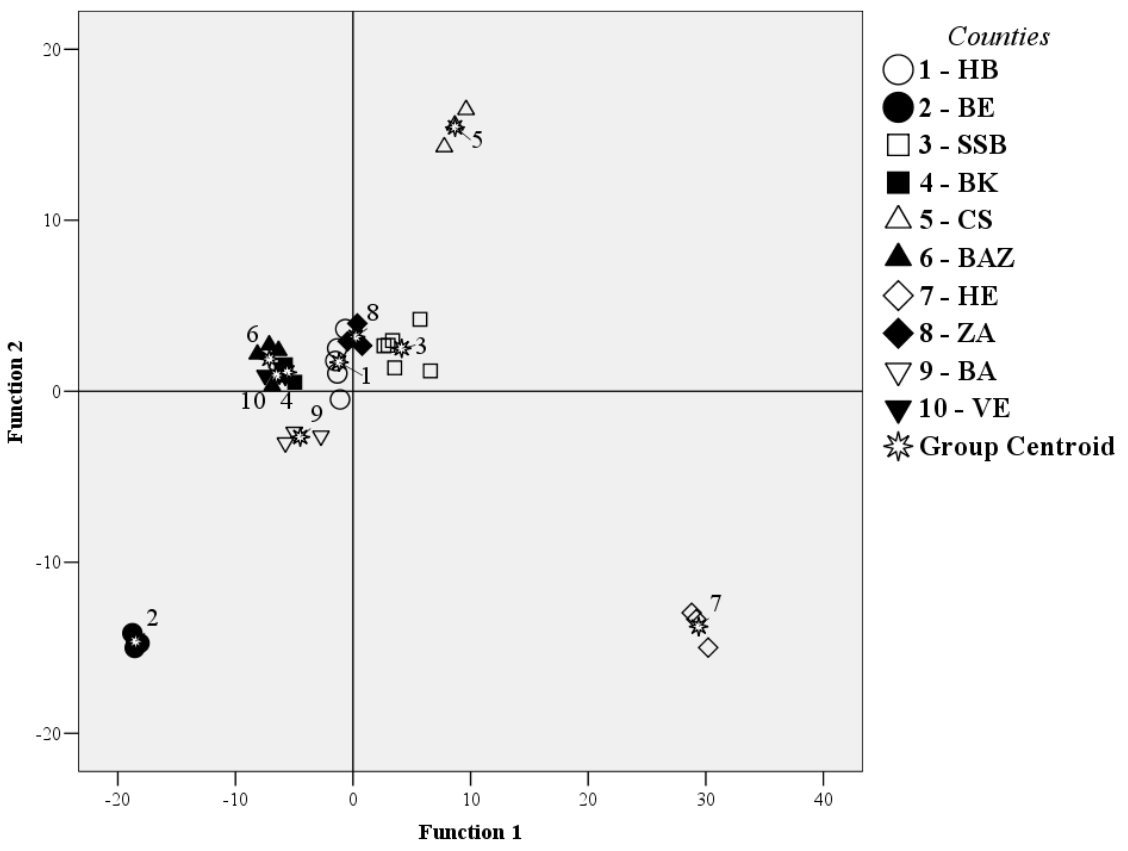

Eight canonical discriminant functions were used in this analysis. The correlations was very high in case of first, second, third, fourth and fifth function with 0.997, 0.994, 0.992, 0.985 and 0.966 value of canonical correlation. In case of sixth function this value was lower (0.860) and the seventh and eighth function showed the lowest values (0.543 and 0.348).

The first function explained $99.4 \%$, the second $98.8 \%$, the third $98.4 \%$, the fourth $97.0 \%$, the fifth $93.3 \%$, the sixth $74.0 \%$, the seventh $29.5 \%$ and the eighth only $12.1 \%$.

In the first dimension the honeys from HE (29.4) showed the highest group centroid followed by honeys from CS (8.68), SSB (4.13), ZA (0.23), 
HB (-1.19), BA (-4.49), BK (-5.60), VE (-6.51), BAZ (-7.12) and BE (-18.5). In the second dimension the honeys from CS (15.4) showed the highest group centroid followed by samples from ZA (3.19), SSB (2.51), BAZ (1.90), HB (1.70), BK (1.11), VE (0.93), BA (-13.8) and BE (-14.6).

According to the cross-validation in case of honeys from $\mathrm{HB}$ the number of correctly categorized cases was $4(80 \%)$, with 1 sample in the group of BAZ. In case of other samples from different county the percent of correctly categorized cases was $100 \%$. Overall $97.2 \%$ of cross-validated grouped cases were correctly classified.

\section{Conclusion}

In this study 6 macro and 13 micro elements in 36 Hungarian acacia honey samples collected in 10 counties were analysed. The concentration of macro elements decreased in the following order: $\mathrm{K}>\mathrm{P}>\mathrm{S}>\mathrm{Ca}>\mathrm{Mg}>\mathrm{Na}$.

Honeys from $\mathrm{HB}$ showed the highest mean $\mathrm{K}, \mathrm{Mg}, \mathrm{Na}$ and $\mathrm{S}$ concentrations, the highest mean $\mathrm{Ca}$ content was determined in samples from SSB and the highest mean $\mathrm{P}$ concentration was measured in samples from VE. Honeys from BE showed the lowest mean $\mathrm{K}, \mathrm{Ca}, \mathrm{P}$ and $\mathrm{S}$ concentrations, the lowest mean $\mathrm{Mg}$ content was measured in samples from CS and the lowest mean $\mathrm{Na}$ content was determined in samples from VE. Statistically verified differences were established mainly in case of mean $\mathrm{Na}, \mathrm{P}$ and $\mathrm{S}$ concentrations of honeys from different counties.

Based on LDA, the analysis of macro element contents did not show obvious results because only $69.4 \%$ of cross-validated grouped cases were correctly classified. In 5 cases (HB, SSB, CS, $\mathrm{HE}$ and BA) the classification was not successful.

The concentration of micro elements decreased in the following order: $\mathrm{B}>\mathrm{Fe}>\mathrm{Zn}>\mathrm{Al}>\mathrm{Cu}>\mathrm{Mn}>\mathrm{Ni}>\mathrm{As}>\mathrm{Ba}>\mathrm{Sr}>\mathrm{Pb}>\mathrm{Cd}$. The highest mean $\mathrm{Al}$ and $\mathrm{Ba}$ contents were determined in samples from $\mathrm{BE}$, the highest mean $\mathrm{B}$ and $\mathrm{Ni}$ content were measured is samples from $\mathrm{HE}$ and the highest mean $\mathrm{Mn}$ and $\mathrm{Sr}$ contents were determined in samples from HB. Honeys from CS showed the highest mean FE content, samples from ZA showed the highest mean $\mathrm{Cu}$ content and samples from BAZ showed the highest mean $\mathrm{Zn}$ concentration. Examining the toxic elements, every examined honey contained As; however the highest mean As content was determined in samples from SSB. The highest $\mathrm{Pb}$ content was measured a honey from BAZ and the highest $\mathrm{Cd}$ concentration was determined in samples from $\mathrm{HB}$, every samples from this county contained $\mathrm{Cd}$.

In samples from $\mathrm{BK}$ the $\mathrm{Al}$ content was under $\mathrm{DL}$ and the $\mathrm{Zn}$ concentration was determined also under DL in samples from BA. The $\mathrm{Pb}$ and $\mathrm{Cd}$ contents were under DL in many samples. In case of micro elements statistically verified differences were determined mainly in case 
of Fe, $\mathrm{Ni}, \mathrm{Cu}$ and $\mathrm{Sr}$. Based on LDA the analysis of As, B, Ba, Cu, Fe, Mn, $\mathrm{Ni}$ and $\mathrm{Sr}$ the results of cross validation was obvious because the percent correctly classified cases was $97.2 \%$. Therefore 9 groups were correctly classified and in case of only one group (samples from HB) was $80 \%$ this value.

Even though the same botanical origin, the micro element content was suitable for separation of samples from different geographical origin.

\section{References}

Almeida-Silva, M.-Canha, N.-Galinha, C.-Dung, H. M.-Freitas, M. C.-Sitoe, T. (2011): Trace elements in wild and orchard honeys. Applied Radiation and Isotopes. 69: 1592-1595.

Czipa, N.-Diósi, G.-Phillips, C.-Kovács, B. (2017): Examination of honeys and flower as soil element indicator. Environmental Monitoring and Assessment.

Czipa, N.-Alexa, L.-Phillips, C.-Kovács, B. (2018): Macro-element ratios provide improved identification of the botanical origin of mono-floral honeys. European Food Research and Technology.

FAOSTAT (2018): Production share by region. http://www.fao.org/faostat/ en/\#data/QL. Accessed 09 May 2018.

Hernández, O. M.-Fraga, J. M. G.-Jiménez, A. I.-Arias, J. J. (2005): Characterization of honey from the Canary Islands: Determination of the mineral content by atomic absorption spectrophotometry. Food Chemistry. 93: 449-458.

Kabata-Pendias, A.-Mukherjee, A. B. (2007): The biosphere. In Trace elements from siol to human. Berlin. Springer-Verlag.

Kovács, B.-Györi, Z.-Prokisch, J.-Loch, J.-Dániel, P. (1996): A study of plant sample preparation and inductively coupled plasma emission spectrometry parameters. Communication in Soil Science and Plant Analysis. 27. 5-8: 11771198.

MSZ 6950-3:1977. Magyar Szabvány. Méz - Mikroszkópos vizsgálat.

Pohl, P.-Stecka, H.-Greda, K.-Jammroz, P. (2012): Bioaccessibility of Ca, Cu, Fe, Mg, $\mathrm{Mn}$ and $\mathrm{Zn}$ from commercial bee honeys. Food Chemistry. 134: 392-396. 